\title{
Pharmacologic Characterization of ALD1910, a Potent Humanized Monoclonal Antibody against the Pituitary Adenylate Cyclase-Activating Peptide ${ }^{\mathbb{S}}$
}

\author{
Cristina Moldovan Loomis, Benjamin Dutzar, Ethan W. Ojala, Lee Hendrix, Charlie Karasek, \\ Michelle Scalley-Kim, Jenny Mulligan, Pei Fan, Jens Billgren, Vanessa Rubin, Heidi Boshaw, \\ Gayle Kwon, Sam Marzolf, Erica Stewart, David Jurchen, Susan M. Pederson, \\ Lisa Perrino McCulloch, Brian Baker, Roger K. Cady, John A. Latham, Dan Allison, \\ and Leon F. Garcia-Martinez
}

Alder BioPharmaceuticals, Inc., Bothell, Washington

Received September 7, 2018; accepted December 27, 2018

\begin{abstract}
Migraine is a debilitating disease that affects almost $15 \%$ of the population worldwide and is the first cause of disability in people under 50 years of age, yet its etiology and pathophysiology remain incompletely understood. Recently, small molecules and therapeutic antibodies that block the calcitonin gene-related peptide (CGRP) signaling pathway have reduced migraine occurrence and aborted acute attacks of migraine in clinical trials and provided prevention in patients with episodic and chronic migraine. Heterogeneity is present within each diagnosis and patient's response to treatment, suggesting migraine as a final common pathway potentially activated by multiple mechanisms, e.g., not all migraine attacks respond to or are prevented by anti-CGRP pharmacological interventions. Consequently, other unique mechanisms central to migraine pathogenesis may present new targets for drug development. Pituitary adenylate cyclase-activating peptide (PACAP) is an
\end{abstract}

attractive novel target for treatment of migraines. We generated a specific, high-affinity, neutralizing monoclonal antibody (ALD1910) with reactivity to both PACAP38 and PACAP27. In vitro, ALD1910 effectively antagonizes PACAP38 signaling through the pituitary adenylate cyclase-activating peptide type I receptor, vasoactive intestinal peptide receptor 1 , and vasoactive intestinal peptide receptor 2. ALD1910 recognizes a nonlinear epitope within PACAP and blocks its binding to the cell surface. To test ALD1910 antagonistic properties directed against endogenous PACAP, we developed an umbellulone-induced rat model of neurogenic vasodilation and parasympathetic lacrimation. In vivo, this model demonstrates that the antagonistic activity of ALD1910 is dosedependent, retaining efficacy at doses as low as $0.3 \mathrm{mg} / \mathrm{kg}$. These results indicate that ALD1910 represents a potential therapeutic antibody to address PACAP-mediated migraine.

\section{Introduction}

Migraine is a debilitating neurologic disease that affects almost $15 \%$ of the population worldwide and is considered by the World Health Organization to be the leading cause of disability in the world for people under 50 (Steiner et al., 2013, 2018). Migraine pathophysiology is complex, characterized by a genetic/epigenetic predisposition and substantial phenotypic heterogeneity (Durham, 2016; Goadsby et al., 2017; Guo, 2017; Hoffmann et al., 2017). Despite its severity and prevalence, migraine is still poorly understood, underscoring a clear unmet therapeutic need for many patients. The gold standard of acute migraine therapy remains oral triptan treatment; however, its use is limited by its propensity to

https://doi.org/10.1124/jpet.118.253443.

S This article has supplemental material available at jpet.aspetjournals.org. induce medication-overuse headache with frequent use and rare but potentially serious cardiovascular and cerebrovascular adverse events (Loder, 2010; Russo, 2015; Obermann and Holle, 2016; Lukacs et al., 2017).

Pioneered by the successful clinical development of therapeutic antibodies targeting the calcitonin gene-related peptide (CGRP) signaling pathway, monoclonal antibodies have recently emerged as a promising new drug class for migraine prevention (Edvinsson, 2018; Edvinsson et al., 2018). Monoclonal antibodies have several advantages over previous existing therapy, including limited off-target effects, high efficacy, sustained durability with a long half-life allowing for monthly to quarterly administration, improved adherence to treatment, and a good tolerability profile (Edvinsson et al., 2018; Levin et al., 2018). Thus, although the long-term safety profile outside a clinical trial setting remains to be determined, anti-CGRP monoclonal antibodies are positioned to be optimal therapies for migraine

ABBREVIATIONS: Ab, antibody; BSA, bovine serum albumin; CGRP, calcitonin gene-related peptide; CPP, cell-penetrating peptide; ELISA, enzyme-linked immunosorbent assay; FACS, fluorescence-activated cell sorter; HTRF, homogeneous time resolved fluorescence; IN, intranasally; PACAP, pituitary adenylate cyclase-activating peptide; PAC1-R, pituitary adenylate cyclase-activating peptide type I receptor; SA-PE, phycoerythrin-conjugated streptavidin; SPR, surface plasmon resonance; VIP, vasoactive intestinal peptide; VPAC1-R, vasoactive intestinal peptide receptor 1; VPAC2-R, vasoactive intestinal peptide receptor 2; N-term, N-terminal; C-term, C-terminal; PBS, phosphate-buffered saline. 
prevention. Recent phase 3 clinical data have shown that several different antibody therapies targeting the CGRP biology are effective with acceptable tolerability and safety profiles, with erenumab-aooe, galcanezumab-gnim, and fremanezumab-vfrm receiving approval from the Food and Drug Administration this year [Khan et al., 2017; Edvinsson, 2018; Edvinsson et al., 2018; Aimovig (erenumab-aooe) prescribing information, Amgen; Emgality (galcanezumab-gnim) prescribing information, Eli Lilly; Ajovy (fremanezumab-vfrm) prescribing information, Teva]. However, in all trials to date, there have been significant numbers of patients who did not respond to CGRP-targeted treatment, highlighting the complexity and heterogeneity of migraine biology as well as the need for additional alternative treatments (Russo, 2015; Khan et al., 2017). Due to the lack of clinical data at this time, it is unclear whether targeting pituitary adenylate cyclase-activating peptide (PACAP) for migraine prevention is complementary, synergistic, or distinct from CGRP antagonism.

PACAP is a multifunctional neuropeptide that has been implicated in migraine pathophysiology (reviewed by Schytz et al., 2010b; Kaiser and Russo, 2013; Lukacs et al., 2017; Vollesen and Ashina, 2017; Rubio-Beltrán et al., 2018). PACAP is a member of the secretin/vasoactive intestinal peptide (VIP)/ growth hormone-releasing hormone family and exists in two $\alpha$-amidated active forms, one composed of 38 amino acids and a second composed of 27 amino acids (PACAP38 and PACAP27, respectively) (Miyata et al., 1990). Both peptides share the same N-terminal 27-amino acid sequence and are produced from the same precursor protein, prepro-PACAP (Moody et al., 2011). Of the two, PACAP38, is the more prevalent form, representing up to $90 \%$ of PACAP forms in mammalian tissues (Arimura et al., 1991; Vaudry et al., 2009; Kaiser and Russo, 2013). PACAP is widely distributed in the brain and peripheral organs, such as the endocrine system, gonads, sympathetic neurons, respiratory system, gastrointestinal tract, cardiovascular system, and urogenital tracts (Vaudry et al., 2009; Schytz et al., 2010b; Tajti et al., 2015). PACAP is expressed, along with its receptors, throughout the nervous system, including distinct areas suggestive of a role in migraine pathophysiology, such as the trigeminovascular system, trigeminal ganglia, trigeminal nucleus caudalis, dorsal horn of the spinal cord, brainstem, hypothalamus, pituitary, and otic and sphenopalatine ganglions (Tajti et al., 1999, 2001; Uddman et al., 1999, 2002; Csati et al., 2012a; Goadsby et al., 2017).

A mechanistic role for PACAP38 in migraine is supported by several clinical observations: 1) human provocation studies showed that an infusion of PACAP38 in migraineurs without aura triggers migraine-like attacks and sustained vasodilation of extracranial arteries (Schytz et al., 2009; Amin et al., 2014; Vollesen and Ashina, 2017); 2) PACAP38-induced migraines are associated with photophobia, phonophobia, and nausea and respond to triptans (Amin et al., 2012, 2014); 3) plasma levels of PACAP38 are elevated during migraine attacks (ictal) as compared with interictal levels in humans (Tuka et al., 2013); and 4) in patients with migraine headache, plasma PACAP levels decrease after sumatriptan treatment correlating with headache amelioration (Zagami et al., 2014).

A monoclonal antibody targeting the PACAP pathway may be beneficial for the prophylactic treatment of migraine (Kaiser and Russo, 2013; Tajti et al., 2015; Vollesen and Ashina, 2017; Rubio-Beltrán et al., 2018). In this communication, we report ALD1910, a potent neutralizing monoclonal antibody targeting
PACAP, which blocks PACAP signaling through the pituitary adenylate cyclase-activating peptide type I receptor (PAC1-R), vasoactive intestinal peptide receptor 1 (VPAC1-R), and vasoactive intestinal peptide receptor 2 (VPAC2-R) and inhibits endogenously released PACAP in vivo. Published literature supports a role for PACAP as a cell-penetrating peptide, and as such can readily cross the cellular plasma membrane in a receptorindependent format (Doan et al., 2012a; Tchoumi Neree et al., 2014; Neree et al., 2015). Unlike antibodies directed to the N-terminal region of PACAP, we demonstrate that ALD1910 does not lead to accumulation of antibody-antigen complexes on the cell surface. ALD1910 is being developed for migraine prevention.

\section{Materials and Methods}

Cell Lines and Peptides. Rat pheochromocytoma PC12 cells endogenously expressing rat PAC1-R were obtained from the Japanese Collection of Research Bioresources Cell Bank (catalog number JCRB0733; Osaka, Japan). Human neuroblastoma SH-SY5Y cells endogenously expressing human PAC1-R were obtained from the American Type Culture Collection (catalog number CRL-2266; Manassas, VA). CHO-K1 cells were obtained from the American Type Culture Collection (catalog number CCL-61) and were stably transfected with either human VPAC1-R cDNA (NM_004624) or human VPAC2-R cDNA (NM_003382). PACAP38 and PACAP27 peptides were obtained from American Peptide (catalog numbers 34-0-20 and 34-0-40; Vista, CA), unless specified otherwise. VIP peptide was obtained from American Peptide (catalog number 48-1-10). N-term and C-term biotinylated PACAP38 peptides were obtained from AnaSpec (catalog numbers 23590 and 23648, respectively; Fremont, CA), N-term biotinylated PACAP27 peptide was obtained from American Peptide (catalog number 370733), and N-term biotinylated VIP peptide was obtained from AnaSpec (catalog number 23594).

Generation of ALD1910 Antibody. New Zealand white rabbits were initially immunized with PACAP38 and keyhole limpet hemocyanin in combination with complete Freund's adjuvant. Subsequent immunizations were repeated with a combination of PACAP38, keyhole limpet hemocyanincross-linked PACAP38, and incomplete Freund's adjuvant until a robust polyclonal titer was achieved as determined by enzyme-linked immunosorbent assay (ELISA) binding to biotinylated PACAP38. Antibodies against PACAP38 were identified by ELISA antigen recognition of conditioned B cell culture supernatants as previously described (Lightwood et al., 2006). To identify specific anti-PACAP38 antibodies that do not recognize VIP, PACAP38 reactive wells were further tested by ELISA for binding to VIP. PACAP38 reactive supernatants were evaluated for potency as measured by their ability to block cAMP accumulation in PACAP38stimulated PC12 cells (cAMP HTRF (homogeneous time resolved fluorescence) kit, catalog number 62 AM4PEC; Cisbio, Bedford, MA). ALD1910 was humanized by grafting its rabbit CDRs (complementaritydetermining regions) into a human framework as previously described (Riechmann et al., 1988).

ALD1910 Binding Kinetics. ALD1910 binding affinity for PACAP38 and PACAP27 was estimated using surface plasmon resonance (SPR) on a ProteOn XPR36 (Bio-Rad, Hercules, CA) as previously described (Bravman et al., 2006). ALD1910 antibody was immobilized via amine coupling. PACAP38 was diluted in PBST (PBS with Tween) buffer (catalog number P1192; Teknova, Hollister, CA) supplemented with $0.2 \mathrm{M}$ arginine (catalog number 2067-06; J.T. Baker) and $0.2 \mathrm{mg} / \mathrm{ml}$ bovine serum albumin (BSA, catalog number 001-00-162; Jackson ImmunoResearch Laboratories, West Grove, PA), $\mathrm{pH}$ 7. Increasing PACAP38 concentrations (ranging from 1.23 to $100 \mathrm{nM}$ ) were used, and kinetic data were analyzed using ProteOn Manager Software (version 3.1.0.6; Bio-Rad) and fitted using a 1:1 Langmuir binding model. To determine binding affinity for VIP, peptide concentrations $12.3 \mathrm{nM}$ up to $1000 \mathrm{nM}$ were used. 
Inhibition of PACAP38- or PACAP27-Induced Signaling via PAC1-R. ALD1910 antibody serial dilutions starting at $33 \mathrm{nM}$ were incubated with either PACAP38 or PACAP27 (final concentrations were $100 \mathrm{pM}$ and $1 \mathrm{nM}$, respectively, for PC12 cells; $400 \mathrm{pM}$ and $1 \mathrm{nM}$, respectively, for SH-SY5Y cells) for 1 hour at $37^{\circ} \mathrm{C}$. PAC1-R-expressing cells (PC12 or SH-SY5Y) were washed and resuspended at $1 \times 10^{6}$ cells $/ \mathrm{ml}$ in cell culture medium. Cells $(20 \mu \mathrm{l})$ and antigen/antibody complex $(20 \mu \mathrm{l}$ ) were transferred to an HTRF plate (catalog number 3693; Corning, Corning, NY) and shaken at room temperature for 30 minutes. Following the incubation, $20 \mu \mathrm{l}$ of Europium $\left(\mathrm{Eu}^{3+}\right)$ donor cryptate-labeled monoclonal antibody anti-cAMP and $20 \mu \mathrm{l}$ of acceptor d2-labeled cAMP in lysis buffer were added according to the manufacturer's instructions (cAMP HTRF kit, catalog number 62 AM4PEC; Cisbio), and the plate was incubated for 1 hour while shaking. Following incubation, plates were read (excitation $330 \mathrm{~nm}$, emission 620/665 nm), and the 620:665 emission ratio was graphed.

Inhibition of PACAP38-Induced Signaling via VPAC1-R and VPAC2-R. ALD1910 was serially diluted and incubated with either 5 nM PACAP38 (VPAC1-R) or 1 nM PACAP38 (VPAC2-R) for 1 hour at $37^{\circ} \mathrm{C}$. VPAC1-R- or VPAC2-R-expressing CHO-K1 cells were detached, washed, and resuspended to a final concentration of $1 \times 10^{6}$ cells per ml in culture medium [F-12K medium, $10 \%$ fetal bovine serum, $1.25 \mathrm{mg} / \mathrm{ml}$ G418 (catalog number LS10131027; Gibco, Carlsbad, CA)]. Cells (20 $\mu \mathrm{l}$ ) and antigen/antibody complex $(20 \mu \mathrm{l})$ were transferred to an HTRF plate (catalog number 3693; Corning) and shaken at room temperature for 30 minutes. Following the incubation, $20 \mu \mathrm{l}$ of $\mathrm{Eu}^{3+}$ donor cryptate-labeled monoclonal antibody anti-cAMP and $20 \mu \mathrm{l}$ of acceptor d2-labeled cAMP in lysis buffer were added according to the manufacturer's instructions (cAMP HTRF kit, catalog number 62 AM4PEC; Cisbio), and the plate was incubated for 1 hour while shaking. Following incubation, plates were read (excitation $330 \mathrm{~nm}$, emission 620/665 nm), and the 620:665 emission ratio was determined.

Inhibition of PACAP Binding to Human PAC1-R. ALD1910 antibody at an initial concentration of $30 \mathrm{nM}$ was serially diluted in incubation buffer [50 mM Hepes (pH 7.4), $1 \mathrm{mM} \mathrm{CaCl}_{2}, 5 \mathrm{mM} \mathrm{MgCl}_{2}$, $0.2 \% \mathrm{BSA}]$ and preincubated at $25^{\circ} \mathrm{C}$ for 30 minutes with $0.1 \mathrm{nM}\left[{ }^{125} \mathrm{I}\right]-$ labeled PACAP27 in incubation buffer. The antibody: $\left[{ }^{125} \mathrm{I}\right]-$ labeled PACAP27 mixture was then mixed with $0.5 \mu \mathrm{g}$ of cell membranes derived from Chem-1 cells expressing human recombinant PAC1-R long isoform (GeneBank NM_001118) in incubation buffer. The mixture was then incubated for 1 hour at $25^{\circ} \mathrm{C}$. Following incubation, the samples were filtered and washed, and the filters were counted. Nonspecific binding to the cell membranes was estimated using $0.1 \mu \mathrm{M}$ PACAP27. $\mathrm{IC}_{50}$ values were determined by a nonlinear, least-squares regression analysis using MathIQ (ID Business Solutions Ltd., Guildford, UK). $\mathrm{K}_{\mathrm{i}}$ values were calculated using the equation of Cheng and Prusoff (1973) using the observed $\mathrm{IC}_{50}$ for the tested compounds, the concentration of radioligand used in the assay, and the historical values for the $\mathrm{K}_{\mathrm{D}}$ of the ligand (obtained experimentally).

ALD1910 Epitope Determination. PACAP38 peptides were synthesized with a single point mutation in each position, replacing the native amino acid with an alanine (Ala). In positions 18,24 , and 25 , the native Ala was replaced with valine (Val). Binding of ALD1910 to PACAP38 and each mutant peptide was measured using SPR on a ProteOn XPR36. ALD1910 antibody was immobilized onto a ProteOn GLC sensor chip (Bio-Rad Laboratories) at $25^{\circ} \mathrm{C}$. The chip surface was allowed to re-equilibrate using $1 \times$ HBS-EP + (Hepes-buffered salineEDTA Polysorbate) with the following additives: $0.2 \mathrm{M}$ arginine $\mathrm{HCl}$ (to reduce nonspecific binding), $0.2 \mathrm{mg} / \mathrm{ml} \mathrm{BSA} \mathrm{(as} \mathrm{carrier),} \mathrm{and} 0.005 \%$ sodium azide (preservative). Stock solutions of PACAP38 peptide or alanine/valine mutant peptides $(100 \mathrm{nM})$ were used to query individual spots on the chip surface with flow rates of $100 \mu \mathrm{l} / \mathrm{min} \times 120$ seconds and allowed to dissociate for 600 seconds. Chip surfaces were regenerated between analytes by the addition of $0.85 \%$ phosphoric acid alternating with $50 \mathrm{mM}$ EDTA in $0.5 \%$ SDS.

PACAP38 and PACAP27 Binding to Cell Surface. All cell incubations were performed on ice. N-term biotinylated PACAP38 or PACAP27 (final $100 \mathrm{nM}$ ) was preincubated with $\mathrm{PE}$ (phycoerythrin)-conjugated streptavidin (SA-PE, 1:200 dilution, catalog number 016-110-084; Jackson ImmunoResearch) in fluorescence-activated cell sorter (FACS) buffer ( $2 \%$ fetal bovine serum in DPBS (Dulbecco's PBS) modified with calcium and magnesium, catalog number SH30028.03; HyClone, Logan, UT). CHO-K1 cells were harvested (scraped), counted, and resuspended at $1.5 \times 10^{5}$ cells $/ \mathrm{ml}$ in FACS buffer. Cells $(100 \mu \mathrm{l})$ were incubated with $100 \mu \mathrm{l}$ of the peptide:SA-PE mixture on ice for 45 minutes in the dark, followed by two washes and resuspension in $200 \mu$ l of FACS buffer containing propidium iodide (catalog number 51-66211E; BD Biosciences, San Jose, CA) and analyzed by flow cytometry using the BD Accuri C6 flow cytometer instrument (BD Biosciences). Propidium iodide-negative cells were selected for analysis. For antibody inhibition of PACAP38 binding studies, a C-term biotinylated PACAP38 peptide was used. Serially diluted ALD1910 or N-term-specific anti-PACAP38 antibody was added to the peptide:SA-PE preincubation mixture prior to incubation with the cells.

PACAP38-Mediated Antibody Binding to the Cell Surface. All cell incubations were performed on ice. PACAP38 (100 nM final) was preincubated with serially diluted ALD1910 or N-term-specific anti-PACAP38 antibody and donkey anti-human Fc antibody-conjugated fluorescein isothiocyanate (1:33 dilution, catalog number 709-096-098; Jackson ImmunoResearch) in FACS buffer at room temperature for 30 minutes. CHO-K1 cells were harvested, counted, and resuspended at $1.5 \times 10^{5} \mathrm{cells} / \mathrm{ml}$ in FACS buffer. Resuspended CHO-K1 cells $(100 \mu \mathrm{l})$ were incubated with $100 \mu \mathrm{l}$ of the peptide:antibody:anti-human Fc antibody mixture on ice for 45 minutes in the dark, followed by two washes and resuspension in $200 \mu \mathrm{l}$ of FACS buffer containing propidium iodide (catalog number 51-66211E; BD Biosciences) and analyzed by flow cytometry using the BD Accuri C6 flow cytometer instrument (BD Biosciences). Propidium iodide-negative cells were selected for analysis.

In Vivo Umbellulone-Induced Increased Facial Temperature and Lacrimation Model. Studies were conducted at Bolder BioPATH (Boulder, CO) according to protocols approved by their Institutional Animal Care and Use Committee. Adult male Sprague-Dawley rats (Envigo Inc., Indianapolis, IN) were cared for, and all procedures complied with the Animal Welfare Act, the Guide for the Care and Use of Laboratory Animals as adopted and promulgated by the US National Institutes of Health, and were approved by the institution's Animal Care and Use Committee. Animals were housed three to five per cage in shoebox polycarbonate cages with wire tops, wood-chip bedding, and suspended food and water bottles. Animal care including room, cage, and equipment sanitation conformed with the National Research Council guide for the care and use of laboratory animals and the institution's applicable standard operating procedures. Animals were acclimated for 9 days prior to being placed in the study. An attending veterinarian was on site or on call during the live phase of the study. During the acclimation and study periods, animals were housed in a laboratory environment with temperatures ranging $67-76^{\circ} \mathrm{F}$ and a relative humidity of $30 \%-70 \%$. Automatic timers provided 12 hours of light and 12 hours of dark. Animals were allowed access ad libitum to Harlan Teklad Rodent Chow and fresh municipal tap water. On study day 0 , animals in each group were weighed and randomized into treatment groups by body weight. Animals were then anesthetized with inhaled isoflurane (catalog number 502017; VetOne, Boise, ID), and $0.2 \mu \mathrm{mol} / \mathrm{kg}$ of umbellulone (catalog number SML0782-25MG; Sigma-Aldrich, St. Louis, MO) or vehicle (0.5\% dimethylsulfoxide in PBS) in a $50-\mu \mathrm{l}$ volume were administered intranasally (IN) per rat into the right nostril over a 5 -second period. At predose and 5 minutes post IN dosing, nose and right foot temperatures were taken with a Thermoworks (American Fork, UT) TW2 IR thermometer with emissivity set to 0.97. The thermometer was held $2.5 \mathrm{~cm}$ from the nose or footpad for the reading. Sixty minutes post IN dosing, animals were anesthetized, and a modified (by cutting $2 \mathrm{~mm}$ off width from the supplied 5-mmwide test strip, resulting in a test strip $3 \mathrm{~mm}$ wide) Schirmer's test strip (catalog number 063059; Merck Animal Health, Madison, NJ) was placed on the medial side of the right lower eyelid for a period of 5 minutes. After 5 minutes, the test strip was read for tear production 
using the preprinted millimeter hash marks on the strip. Administration of compounds was as follows: HC-030031 (catalog number H4415; Sigma-Aldrich) was administered at $100 \mathrm{mg} / \mathrm{kg}$ intragastrically 1 hour prior to umbellulone exposure; hexamethonium chloride (catalog number H2138; Sigma-Aldrich) was administered at $20 \mathrm{mg} / \mathrm{kg}$ intravenously 5 minutes prior to umbellulone exposure; and sumatriptan (catalog number 3586; Tocris, Minneapolis, MN) was administered at $1 \mathrm{mg} / \mathrm{kg}$ intravenously 1 hour prior to umbellulone exposure. Antibodies (ALD1910, isotype control, anti-CGRP, and anti-PAC1-R antibodies) were administered at $20 \mathrm{mg} / \mathrm{kg}$ intravenously 24 hours prior to umbellulone exposure. For the dose-response study, ALD1910 was administered at $30,3,0.3,0.03$, and $0.003 \mathrm{mg} / \mathrm{kg}$ intravenously 24 hours prior to umbellulone exposure. Sixty minutes after umbellulone exposure, blood was collected from the abdominal aorta and processed for serum to assess antibody levels. ALD1910 and isotype antibody $(\mathrm{Ab})$ concentrations in rat serum were measured using Meso Scale Discovery technology (Meso Scale Diagnostics, Rockville, MD) with a quantification range of $81.9 \mathrm{ng} / \mathrm{ml}$ (lower limit of quantification) to $50,000 \mathrm{ng} / \mathrm{ml}$. Quality controls were made by spiking ALD1910 or isotype control $\mathrm{Ab}$ into $100 \%$ rat serum. Calibration standards were freshly prepared on the day of the assay by spiking ALD1910 or isotype $\mathrm{Ab}$ into $1 \%$ rat serum. All in vivo evaluations were performed in a blinded manner, except for the dose-response study.

\section{Results}

ALD1910 Identification, Specificity, and Binding Kinetics. A large collection of PACAP38 and PACAP27 reactive antibodies were identified from B cell cultures of PACAP38immunized rabbits. A subset of this collection was demonstrated to inhibit PACAP38- and PACAP27-induced signaling, and one of these antibodies, ALD1910, was humanized and further characterized. ALD1910 binds with high affinity to both PACAP38 and PACAP27 $\left(\mathrm{K}_{\mathrm{D}}=22\right.$ and $59 \mathrm{pM}$, respectively), exhibiting a fast on-rate and a slow off-rate (Table 1). The sequence of PACAP38 is identical in human, rat, and mouse (Harmar et al., 2012); therefore, it is expected that ALD1910 will cross-react with PACAP across these species. The PACAP27 amino acid sequence is closely related (68\% identity) to that of VIP (Vaudry et al., 2009). ALD1910 has a much lower affinity for VIP ( $>4000$-fold, $\mathrm{K}_{\mathrm{D}}=91 \mathrm{nM}$ for VIP) than for PACAP38 (Table 1) and does not block VIP-induced cAMP signaling via either VPAC1-R or VPAC2-R when used up to 1000-fold molar excess (data not shown).

ALD1910 Inhibits PACAP38 and PACAP27 Activity In Vitro. PACAP38 and PACAP27 receptor binding initiates signaling, inducing cAMP accumulation in both the human neuroblastoma SH-SY5Y and the rat pheochromocytoma PC12 cell lines via the PAC1-R (Spengler et al., 1993; Colbert et al., 1994; Pisegna and Wank, 1996; Onoue et al., 2002; Lutz et al., 2006). ALD1910 potently inhibits PACAP38- and PACAP27induced cAMP accumulation in SH-SY5Y cells, with $\mathrm{IC}_{50}$ values of 99 and $252 \mathrm{pM}$, respectively (400 pM PACAP38, $1 \mathrm{nM}$

\section{TABLE 1}

ALD1910 binds PACAP38 and PACAP27 with high affinity and selectivity

\begin{tabular}{cccc}
\hline \multicolumn{1}{c}{ Peptide } & $\mathrm{k}_{a}$ & $\mathrm{k}_{\mathrm{d}}$ & $\mathrm{k}_{\mathrm{D}}$ \\
\hline & $M^{-1} s^{-1}$ & $s^{-1}$ & $M$ \\
PACAP38 & $4.5 \mathrm{E}+05$ & $1.0 \mathrm{E}-05$ & $2.2 \mathrm{E}-11$ \\
PACAP27 & $1.7 \mathrm{E}+05$ & $1.0 \mathrm{E}-05$ & $5.9 \mathrm{E}-11$ \\
VIP & $1.4 \mathrm{E}+05$ & $1.3 \mathrm{E}-02$ & $9.1 \mathrm{E}-08$ \\
\hline
\end{tabular}

$\mathrm{k}_{\mathrm{a}}$, association constant; $\mathrm{k}_{\mathrm{d}}$, dissociation constant; $\mathrm{K}_{\mathrm{D}}$, equilibrium constant.
PACAP27; Fig. 1, A and B). In PC12 cells, ALD1910 inhibits PACAP38- and PACAP27-induced cAMP accumulation with $\mathrm{IC}_{50}$ values of 53 and $265 \mathrm{pM}$, respectively (100 pM PACAP38, $1 \mathrm{nM}$ PACAP27; Fig. 1, C and D).

PACAP can signal through VPAC1-R and VPAC2-R (Vaudry et al., 2009; Harmar et al., 2012). ALD1910 fully inhibits, in a dose-dependent manner, PACAP38-induced cAMP accumulation mediated via human VPAC1-R and VPAC2-R stably expressed on CHO-K1 cells with an $\mathrm{IC}_{50}$ of $2.05 \mathrm{nM}(5 \mathrm{nM}$ PACAP38; Fig. 1E) and an $\mathrm{IC}_{50}$ of $0.27 \mathrm{nM}$ (1 nM PACAP38; Fig. 1 F), respectively.

ALD1910 Binds PACAP via a Nonlinear Epitope and Inhibits PACAP Binding to PAC1-R. To determine the epitope on PACAP38 recognized by ALD1910, alanine scanning mutagenesis was used. Where alanine was the wild-type amino acid present, this residue position was mutagenized to valine. Binding of ALD1910 to either wild-type PACAP38 or each mutant peptide was assessed using SPR. The alanine scanning strategy identified PACAP amino acid positions $19,22,23$, or 27 as key features for ALD1910 recognition where binding is significantly affected (Fig. 2), suggesting a nonlinear epitope recognized by ALD1910 on PACAP38. To demonstrate that ALD1910 inhibits binding of PACAP to the PAC1-R, we used $\left[{ }^{125} \mathrm{I}\right]$-labeled PACAP27 and human PAC1-R stably expressed on Chem-1 cell membrane preparations. Preincubation of ALD1910 with $\left.{ }^{[25} \mathrm{I}\right]$-labeled PACAP led to a dose-dependent inhibition of PACAP binding to its receptor on cell membrane preparations, with a $\mathrm{K}_{\mathrm{i}}$ of $0.14 \mathrm{nM}$. Unlabeled peptide PACAP27, used as a positive control in the assay, displayed a $\mathrm{K}_{\mathrm{i}}$ value of $0.48 \mathrm{nM}$ (Fig. 3).

ALD1910 Prevents PACAP38 Binding to the Cell Surface. Both PACAP38 and PACAP27 have been described as cell-penetrating peptides. PACAP38 is reported to be significantly (approximately 5-fold) more efficient than PACAP27 in delivering extracellular cargo into the cytosol (Doan et al., 2012a; Neree et al., 2015). CHO-K1 cells do not express PACAP receptors, and the transport of molecules across the membrane by PACAP as a cell-penetrating peptide is receptor-independent (Doan et al., 2012a,b). The lack of PACAP receptors on CHO-K1 cells was corroborated via functional activity; no cAMP accumulation was measurable upon incubation of this cell line with PACAP38 (data not shown). Our target therapeutic entity profile favored an antibody which, when binding to PACAP, would not itself associate with the cell membrane or be transported into the cell. To test and explore this property, we established a highly sensitive in vitro system to monitor cell membrane association of PACAP:antibody complexes using CHO-K1 cells. We established conditions which enabled us to monitor the binding of PACAP38 to the cell surface of CHO-K1 cells using flow cytometry (Supplemental Fig. 1, A and $\mathrm{B})$. The conditions used were optimized to monitor association of PACAP38 with CHO-K1 cells down to low nanomolar concentrations, whereas under the same conditions, PACAP27 (at micromolar concentrations) was not associated with the cells. We then tested if PACAP38 would tether ALD1910 to the cell surface. ALD1910 prevented binding of PACAP38 to the cell surface (Fig. 4A), whereas a separate N-term-directed anti-PACAP38 antibody did not (Fig. 4B). We were further able to detect the PACAP38:N-term-directed anti-PACAP38 antibody on the cell surface using an anti-Fc antibody for detection; the PACAP38:ALD1910 complex was not detected (Fig. 4C). 
A

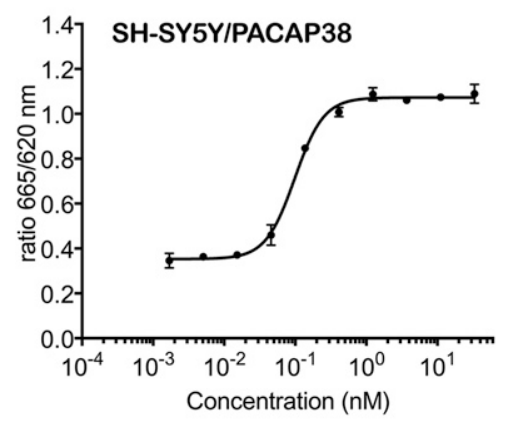

C

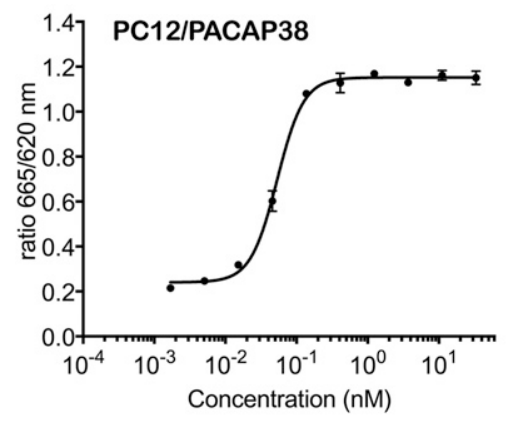

E

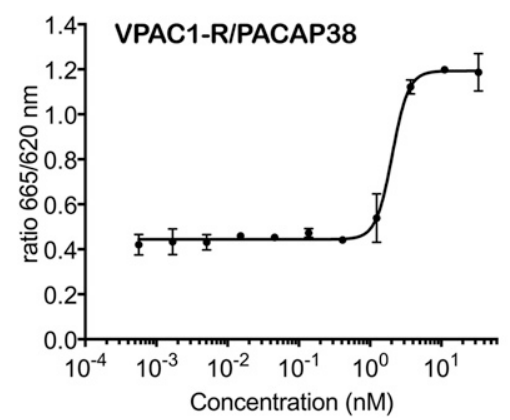

B

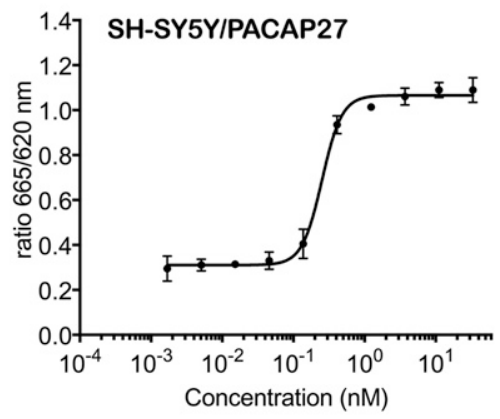

D

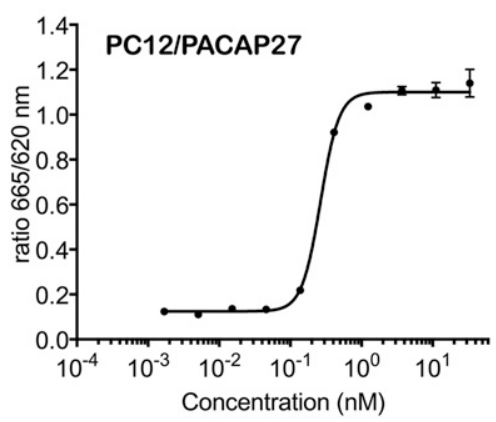

Fig. 1. ALD1910 inhibits PACAP-induced signaling. Human neuroblastoma SH-SY5Y cells were stimulated with 400 pM PACAP38 (A) or with $1 \mathrm{nM}$ PACAP27 (B) in the presence of increasing concentrations of ALD1910. Rat pheochromocytoma PC12 cells were stimulated with 100 pM PACAP38 (C) or with $1 \mathrm{nM}$ PACAP27 (D) in the presence of increasing concentrations of ALD1910. CHO-K1 cells stably expressing human VPAC1-R were stimulated with 5 nM PACAP38 (E), and CHO-K1 cells stably expressing human VPAC2-R were stimulated with $1 \mathrm{nM}$ PACAP38 (F) in the presence of increasing concentrations of ALD1910. Intracellular cAMP accumulation was measured using a competitive HTRF assay. Figures are representative curves from one of the experiments run in duplicate; error bars represent the S.D.
$\mathbf{F}$

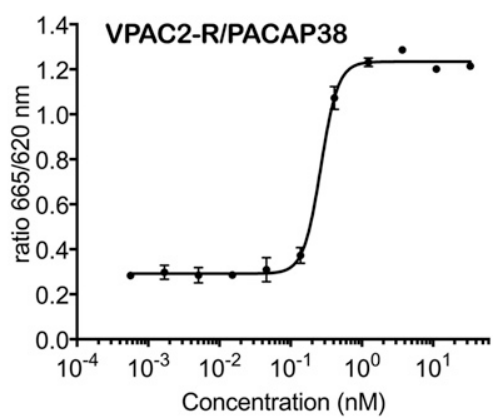

ALD1910 Antagonist Activity In Vivo. To determine the ability of ALD1910 to inhibit endogenously released PACAP, we developed an animal model of TRPA1-induced neurogenic vasodilation and parasympathetic lacrimation using umbellulone based on prior reports (Gottselig and Messlinger, 2004; Nassini et al., 2012). In brief, umbellulone was applied to the nasal mucosa of Sprague-Dawley rats, leading to increased lacrimation and increased facial temperature [used as surrogate for vasodilation (Højland et al., 2015)] compared with vehicle control ( $P=0.014$ and $P=0.0057$, respectively) (Fig. 5, A and B). Pretreatment with a TRPA1-specific smallmolecule antagonist, HC-030031 (McNamara et al., 2007), abolished the effect of umbellulone on facial temperature increase, confirming umbellulone activation of TRPA1 receptor, as previously reported (Edelmayer et al., 2012; Nassini et al., 2012) (Supplemental Fig. 2). In contrast, HC-030031 did not have any effect on lacrimation monitored 2 hours post HC-030031 administration (data not shown). Administration of hexamethonium chloride, a blocker of synaptic transmission in autonomic ganglia (Goadsby, 1991; Gottselig and Messlinger, 2004), inhibited umbellulone-driven lacrimation $(P=0.017)$ but had little/no effect on increased facial temperature (Fig. 5, C and D). Finally, sumatriptan, a $5-\mathrm{HT}_{1 \mathrm{~B} / 1 \mathrm{D}}$ agonist, administered at $1 \mathrm{mg} / \mathrm{kg}$ i.v. inhibited umbellulone-driven lacrimation $(P=0.0009)$ and facial temperature increase $(P=0.0022)$ (Fig. 5, C and D).

Nassini et al. (2012) reported that IN administration of umbellulone leads to increased meningeal blood flow which is inhibited by the CGRP receptor antagonist BIBN4096BS. We tested if CGRP also mediates the umbellulone-induced facial temperature and lacrimation. Administration of an anti-CGRP antibody decreased both umbellulone-induced facial temperature $(P<0.0001)$ and lacrimation $(P<0.05)$ (Fig. 6, A and B). We used this system to query whether PACAP also mediates either the increased facial temperature or lacrimation after IN umbellulone. Animals were treated with ALD1910 24 hours prior to umbellulone challenge to allow efficient biodistribution of the antibody in tissues and to ensure adequate exposure (Dostalek et al., 2013). The half-life of ALD1910 in rats is $188 \pm$ 32 hours (data not shown). Inhibition of PACAP biology using either ALD1910 or an anti-PAC1-R monoclonal antibody led to an inhibition of both umbellulone-induced facial temperature $(P<0.0001)$ and lacrimation $(P<0.05)$ (Fig. 6, A and B). This demonstrates that PACAP, similar to CGRP, is involved in umbellulone-induced neurogenic vasodilation and 

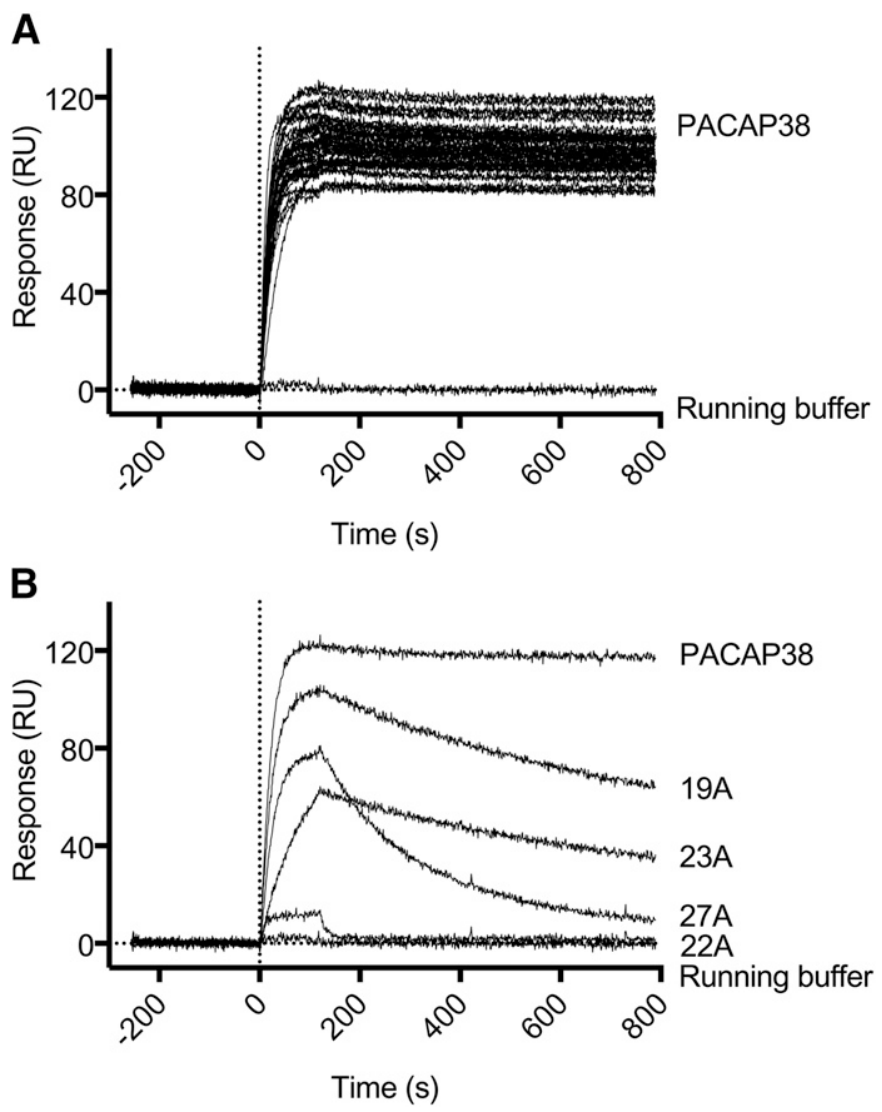

Fig. 2. ALD1910 PACAP binding epitope determination. Binding of ALD1910 and each mutant peptide was detected using SPR. (A) Sensorgrams for amino acids within PACAP38 not involved in ALD1910 binding. (B) Sensorgrams for amino acids within PACAP38 involved in ALD1910 binding. RU (Response Units).

parasympathetic lacrimation. The inhibition of endogenously released PACAP in rats by ALD1910 is dose-dependent, retaining efficacy at doses as low as $0.3 \mathrm{mg} / \mathrm{kg}$ (Fig. 6C). The ALD1910 exposure levels, reported as mean serum concentrations from samples taken 60 minutes post umbellulone challenge, are plotted on the right-hand-side $y$-axis of the temperature doseresponse figure (Fig. 6C).

\section{Discussion}

PACAP38 has emerged as a potentially important signaling molecule in the pathophysiology of migraine (reviewed by Schytz et al., 2010a; Kaiser and Russo, 2013; Tajti et al., 2015; Vollesen and Ashina, 2017; Rubio-Beltrán et al., 2018). While it is currently unclear whether PACAP38 and CGRP mediate overlapping or complementary pathways, there are several reports that indicate that PACAP38 may represent a unique and distinct pathway of migraine. Indeed, human provocation studies have shown that PACAP38 infusion induces unique delayed migraine-like attacks associated with prolonged facial flushing (Ashina et al., 2017). In contrast, the onset of CGRPinduced migraine-like attacks is almost immediate. Another distinction is that PACAP38-induced migraine attacks include premonitory symptoms in almost $50 \%$ of induced migraine-like episodes (Guo et al., 2016).

A variety of factors (both endogenous and exogenous) have the potential to initiate migraine, including mast cell degranulation,

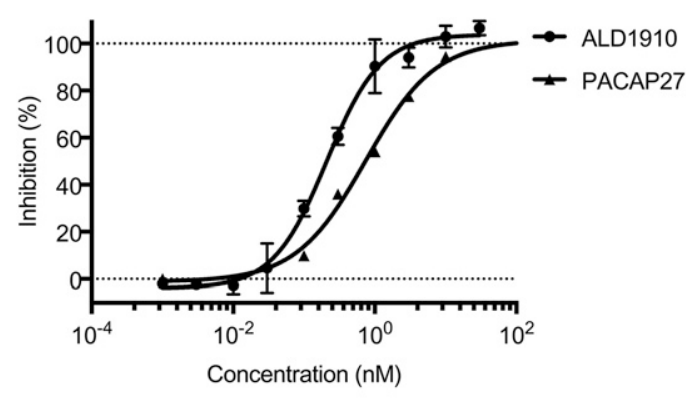

\begin{tabular}{|c|c|c|}
\hline & $\mathrm{IC}_{50}(\mathrm{nM})$ & $\mathrm{K}_{\mathrm{i}}(\mathrm{nM})$ \\
\hline ALD1910 & 0.21 & 0.14 \\
\hline PACAP27 & 0.73 & 0.48 \\
\hline
\end{tabular}

Fig. 3. ALD1910 inhibits binding of $\left[{ }^{125} \mathrm{I}\right]$-labeled PACAP27 to human PAC1-R expressed on Chem-1 cell membrane preparations. ALD1910 was incubated with labeled $\left[{ }^{125} \mathrm{I}\right]-\mathrm{PACAP} 27$ prior to incubation with cell membrane preparations. Unlabeled PACAP27 was used as positive control. Each concentration was tested in duplicate; error bars represent the S.D.

especially when associated with allergic diseases such as allergic rhinitis and asthma (Levy et al., 2006; Jansen-Olesen and Hougaard Pedersen, 2018). Mast cells are proximal to meningeal blood vessels and pain fibers, and they release pronociceptive molecules upon degranulation. Unlike infusion of CGRP, PACAP38 infusion correlates not only with a migraine-like headache but also with long-lasting flushing, which has been suggested to be mediated via degranulation of mast cells (Schytz et al., 2009; Seeliger et al., 2010; Bhatt et al., 2014). In vitro evidence supports PACAP38 secretion by activated human mast cells and potentiation of mast cell degranulation (Okragly et al., 2018). Furthermore, using a rodent closed-cranial window model, Bhatt et al. (2014) and Jansen-Olesen and Hougaard Pedersen (2018) have shown that PACAP38-mediated, but not CGRPmediated, vasodilation of the middle meningeal artery is mast cell-dependent. PACAP38, unlike VIP and PACAP27, is a potent degranulator of rat dural and peritoneal mast cells; this effect is thought to be mediated via phospholipase $\mathrm{C}$ coupled to a yet unidentified receptor (Baun et al., 2012). Activated mast cells within the dura release histamine, prostaglandins, and proinflammatory mediators which can further activate meningeal nociceptors and exacerbate migraine (reviewed by Theoharides et al., 2005; Tajti et al., 2015; Jansen-Olesen and Hougaard Pedersen, 2018; Mason and Russo, 2018).

In addition to mast cell degranulation, a large body of preclinical data support a role for PACAP38 in other areas of migraine pathophysiology, such as vasodilation, trigeminal neuronal activation/sensitization, and photophobia (Boni et al., 2009; Markovics et al., 2012; Syed et al., 2012; Jansen-Olesen et al., 2014; Akerman and Goadsby, 2015). Furthermore, plasma PACAP38 levels are found to be elevated in preclinical models of trigeminovascular stimulation, mirroring increased ictal plasma levels observed in migraine patients (Tuka et al., 2012, 2013; Zagami et al., 2014).

Consistent with a role in migraine, PACAP and all three receptors are expressed in anatomic structures within the trigeminovascular system relevant to migraine pathogenesis: dorsal root ganglia, trigeminal ganglion, trigeminal nucleus caudalis, dural nerve fibers and blood vessels, brainstem structures (such as the periaqueductal gray), and ottic and sphenopalatine ganglia (Uddman et al., 1993, 1999, 2002; Mulder et al., 1994; Tajti et al., 1999, 2001; Fahrenkrug et al., 2000; 
A

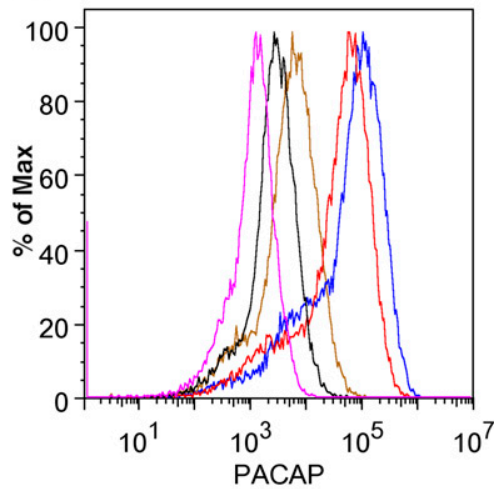

B

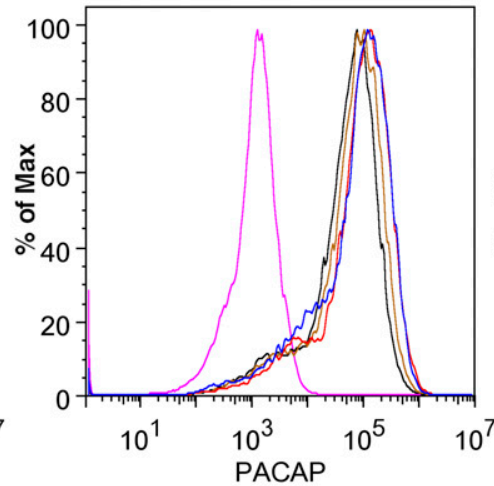

C

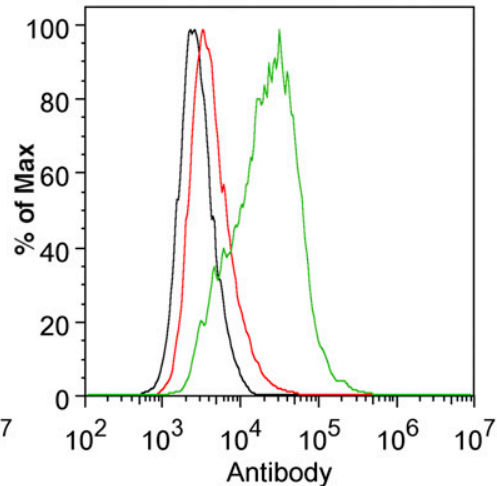

Fig. 4. ALD1910 blocks binding of PACAP38 to cell surface. CHO-K1 cells were stained with a preincubated mix of C-term biotinylated PACAP38 $(100 \mathrm{nM})$ and increasing concentrations of ALD1910 Ab (black line, $62.5 \mathrm{nM}$; brown line, $31.3 \mathrm{nM}$; red line, $15.6 \mathrm{nM}$; blue line, no antibody) (A) or an N-term-directed anti-PACAP antibody (B), and a constant amount of streptavidin-PE (magenta line) prior to FACS analysis. (C) To detect antibody: PACAP38 complexes bound to CHO-K1 cell surface, CHO-K1 cells were stained with a preincubated mix of PACAP38 (100 nM) and 2.5-fold excess of binding sites (125 nM) of ALD1910 Ab (red line), or an N-term-directed anti-PACAP antibody (green line) and a constant amount of fluorescein isothiocyanate-labeled donkey anti-human Fc antibody (black line) prior to FACS analysis.

Csati et al., 2012a; Frederiksen et al., 2018) (reviewed by Tajti et al., 2015; Jansen-Olesen and Hougaard Pedersen, 2018). CGRP-containing sensory fibers originating from the trigeminal ganglion project to the sphenopalatine ganglion, where CGRP receptors and PACAP and its receptors are expressed; this suggests interaction between sensory and parasympathetic systems. PACAP-containing, but not VIP-containing, neurons are found in the trigeminal ganglion and trigeminal nucleus caudalis (Csati et al., 2012a,b). A noteworthy colocalization of PACAP with CGRP in neurons within the trigeminal ganglion has been observed (Eftekhari et al., 2015). The trigeminal ganglion, thought to be the "tuner" with regard to migraine
A

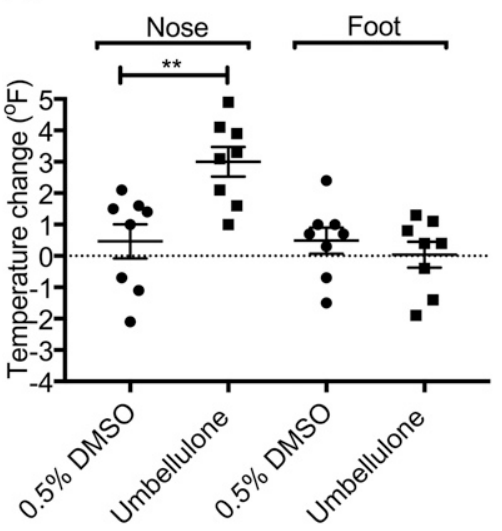

C

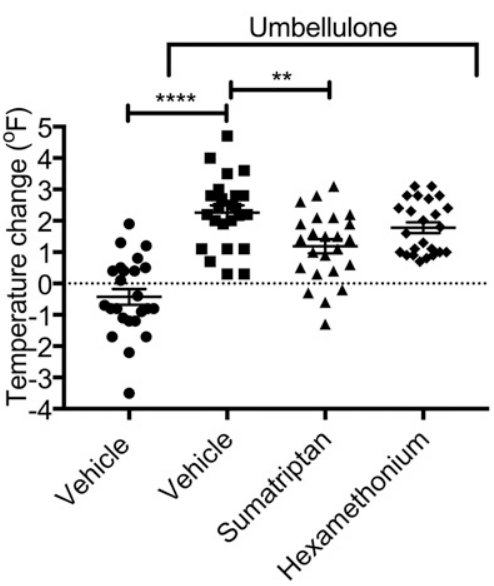

B

Lacrimation

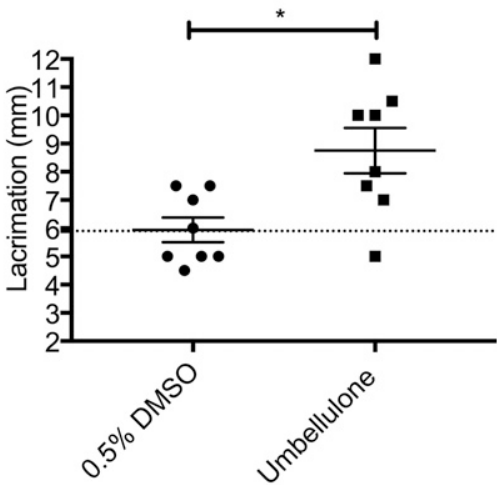

D Lacrimation

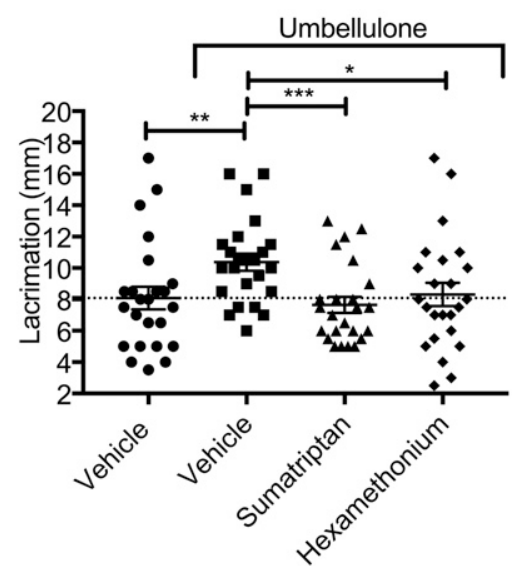

Fig. 5. Characterization of the umbellulone-induced facial temperature and lacrimation model. Intranasal administration of umbellulone, but not vehicle, induced a localized increase in facial (nose) temperature (A) and an increase in lacrimation (B); eight animals per group (Mann-Whitney test). Effect of hexamethonium and sumatriptan in the umbellulone-induced increase in facial temperature $(C)$ and lacrimation (D); 12 animals per group, two independent studies (Mann-Whitney test). $* P<0.05 ; * * P<0.01 ; * * * P<$ $0.001 ; * * * * P<0.0001$. DMSO, dimethylsulfoxide. 


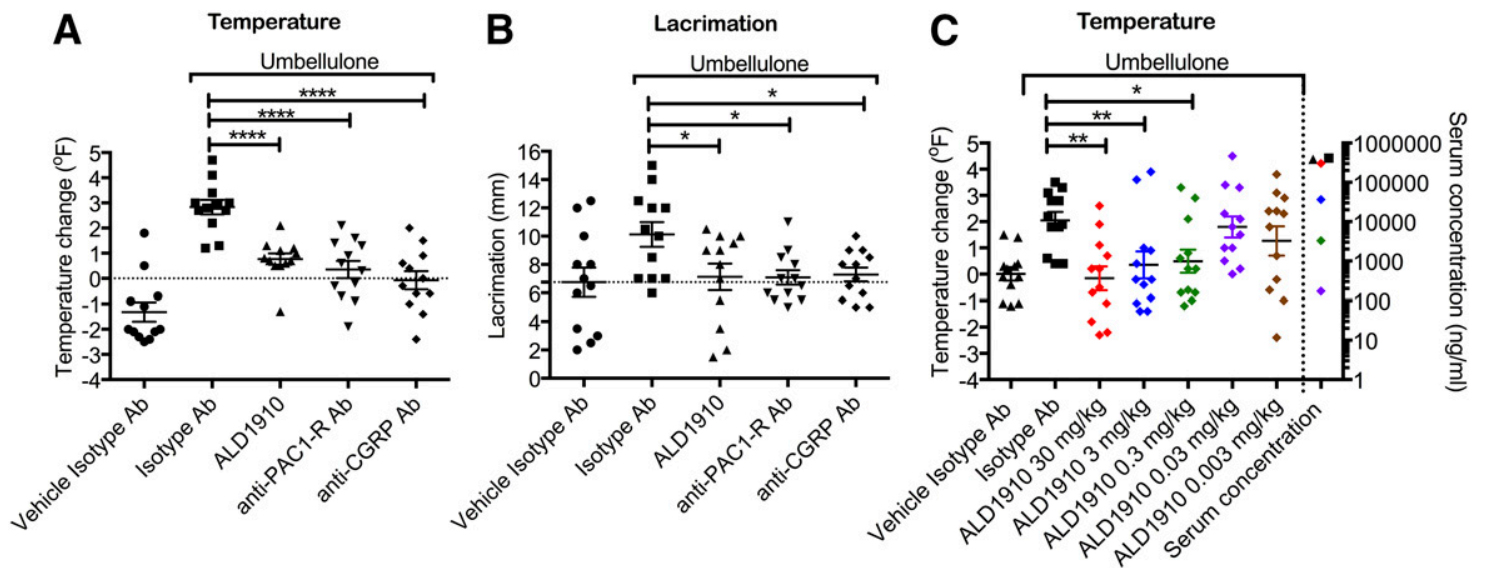

Fig. 6. ALD1910 inhibits endogenously released PACAP. ALD1910, anti-PAC1-R antibody, and anti-CGRP antibody inhibit umbellulone-induced temperature increase (A) and lacrimation (B). The antagonistic activity of ALD1910 in the umbellulone-induced temperature model is dose-dependent. (C) ALD1910 was administered at 30,3,0.3,0.03, and $0.003 \mathrm{mg} / \mathrm{kg} 24$ hours prior to umbellulone exposure. The left $y$-axis shows the facial temperature change $\left({ }^{\circ} \mathrm{F}\right) \pm$ S.E.M. measured 5 minutes post umbellulone exposure relative to baseline. The right $y$-axis shows the mean serum concentration (in nanograms per milliliter) 60 minutes after umbellulone exposure. The serum concentration value for the $0.003 \mathrm{mg} / \mathrm{kg}$ dose was below the limit of detection and thus not represented here; 12 animals per group (Dunnett's multiple comparisons test vs. isotype antibody). ${ }^{*} P<0.05 ; * * P<0.01 ; * * * * P<$ 0.0001 vs. isotype $\mathrm{Ab}(\mathrm{A}-\mathrm{C})$.

pathophysiology, along with the sphenopalatine ganglion are located outside the blood-brain barrier and thus are accessible to antibody therapeutics (Eftekhari et al., 2015; Frederiksen et al., 2018).

In light of these data, it is reasonable to postulate that blocking PACAP38 signaling may be beneficial in the preventive treatment of migraine either in combination with existing therapies or as monotherapy. In fact, a therapeutic monoclonal antibody against PAC1-R is currently in phase II clinical trials in migraine prevention (ClinicalTrials.gov identifier: NCT03238781). Based on the aforementioned preclinical data, alongside peripheral human provocation studies (Amin et al., 2014; Vollesen and Ashina, 2017) and clinical studies correlating ictal PACAP levels in patients (Tuka et al., 2013; Zagami et al., 2014), we discovered and engineered ALD1910, a potent neutralizing anti-PACAP therapeutic monoclonal antibody for development as a preventive treatment of migraine.

Both PACAP38 and PACAP27 forms share the N-terminal 1-27 region, which is responsible for the biologic activity of the peptide (Miyata et al., 1990). PACAP38 constitutes the predominant form; however, both forms of PACAP are widely distributed throughout the body, and the proportions vary between different organs (Arimura et al., 1991; Vaudry et al., 2009). The relative importance of PACAP27 versus PACAP38 in migraine pathophysiology is still unknown; thus, we designed ALD1910 to antagonize both PACAP38 and PACAP27 pharmacology.

PACAP is closely related to VIP, which has pleiotropic physiologic functions, but its infusion did not provoke migrainelike attacks in volunteers with migraine; rather, it has been reported to lead only to a mild headache (Hansen et al., 2006; Rahmann et al., 2008; Amin et al., 2012; Harmar et al., 2012). ALD1910 was selected for further development in part due to its specificity for PACAP and the advantage of a targeted intervention. As such, ALD1910 is 4000-fold more selective for PACAP versus VIP, and it is ineffective at blocking VIP-induced cAMP signaling via either VPAC1-R or VPAC2-R (data not shown).

PAC1-R is selectively activated by PACAP, in contrast to VPAC1-R and VPAC2-R, which are responsive to both VIP and
PACAP peptides. The inability of VIP to induce migraine-like attacks despite inducing marked vasodilation in human provocation studies suggests a role for PAC1-R in migraine (reviewed by Kaiser and Russo, 2013; Goadsby et al., 2017; Vollesen and Ashina, 2017). However, an endogenous localized release of PACAP during a migraine attack may allow for additional contributions from both VPAC1-R and/or VPAC2-R. In this respect, it is noteworthy that all three PACAP receptors (PAC1-R, VPAC1-R, and VPAC2-R) are expressed in key areas of migraine biology, such as the trigeminal ganglion, the trigeminocervical complex, and dural blood vessels (Akerman and Goadsby, 2015). ALD1910 blocks PACAP38and PACAP27-induced signaling via all three receptors. While both forms of PACAP are equivalent stimulators of adenylate cyclase, differential activation of pERK (phosphoERK) or phospholipase $\mathrm{C}$ by PACAP38 has been reported through different PAC1-R splice isoforms and the cell types (Miyata et al., 1990; Pantaloni et al., 1996; Walker et al., 2014). ALD1910 blocks binding of PACAP to its receptor, resulting in not only inhibition of accumulation of cAMP but also blocking of signaling via inositol phosphate and phospho-Erk pathways (data not shown).

ALD1910 inhibits PAC1-R signaling by preventing the ligand-receptor interaction, as ALD1910 potently and competitively inhibits the binding of $\left[{ }^{125} \mathrm{I}\right]$-PACAP27 to human PAC1-R-expressing cell membranes. The ALD1910 epitope (residues 19, 22, 23, and 27, as determined by alanine scan mutagenesis) encompasses the critical region involved in receptor binding (Sun et al., 2007; Kumar et al., 2011).

Cell-penetrating peptides (CPPs), also called protein transduction domains, denote small peptides capable of enabling the transport of molecular cargo across plasma membranes, including large proteins such as antibodies and antibody fragments, by a mechanism not fully understood (Heng and Cao, 2005; Duchardt et al., 2007; Marschall et al., 2011; Ramsey and Flynn, 2015; Dinca et al., 2016). PACAP has been described as a cationic CPP able to transport cargo into the cytosol in a receptor-independent manner more efficiently than the well characterized HIV-Tat CPP (Doan et al., 2012a). 
PACAP CPP properties rely on the cationic properties of the PACAP peptide and its ability to associate with cell surface proteoglycans (Tchoumi Neree et al., 2014; Neree et al., 2015). We focused on identifying anti-PACAP antibodies which would completely inhibit the association of PACAP with the cell surface. Multiple literature reports discuss incomplete target neutralization by antibodies that, while able to inhibit target-receptor interactions, still allowed target-cell surface glycosaminoglycan interactions which resulted in partial antagonism (Burgess et al., 2006; Greenall et al., 2016). We have established that ALD1910 blocks all cell association of PACAP either through its receptor or through reported proteoglycan interactions. This is in contrast to an N-terminal-directed antibody.

Migraine is a complex neurologic disease characterized by debilitating headache, as well as associated symptoms including nausea, photophobia, and phonophobia (Goadsby et al., 2017). In addition, patients with migraine as well as patients with cluster headache often experience cranial autonomic disturbances, such as lacrimation, conjunctival injection, nasal congestion/rhinorrhea, and forehead/facial sweating (Barbanti et al., 2002, 2016). These autonomic symptoms are thought to be caused by activation of the trigemino-parasympathetic reflex due to hyperexcitability of the trigeminal afferents (Barbanti et al., 2002; Khan et al., 2014). Animal models of trigeminoparasympathetic reflex can be reproduced by noxious electrical or chemical stimulation of the facial mucosa that elicits vasodilation of the cranial vessels or the orofacial area and provokes lacrimation (Goadsby, 1991; Mizuta et al., 2002; Gottselig and Messlinger, 2004; Akerman et al., 2012; Akerman and Goadsby, 2015). Exposure to the scent of the California bay laurel Umbellularia californica, also known as the "headache tree," can cause severe headaches and cluster headache attacks in humans (Benemei et al., 2010; Nassini et al., 2012). In animal models, the active ingredient, umbellulone, has been demonstrated to activate the trigeminovascular system via the TRPA1 receptor, leading to meningeal vasodilation and facial allodynia (Kunkler et al., 2011; Edelmayer et al., 2012; Nassini et al., 2012). We used application of umbellulone to the nasal mucosa of rats along with monitoring lacrimation and increased facial temperature as a surrogate for vasodilation. Confirming previous reports, we showed that umbellulone activity is mediated via the TRPA1 receptor, and CGRP as pretreatment via the TRPA1 inhibitor HC-030031 or an anti-CGRP antibody prevents the increase in facial temperature. We demonstrated that PACAP and the PAC1-R axis also mediate umbellulonedriven neurogenic vasodilation and parasympathetic activation. This finding was validated by the inhibition of umbellulone action with either an anti-PACAP antibody (ALD1910) or an anti-PAC1-R antibody. ALD1910 shows dose-dependent in vivo antagonistic activity in this model, retaining efficacy at doses as low as $0.3 \mathrm{mg} / \mathrm{kg}$.

ALD1910 is a potent neutralizing monoclonal antibody with high affinity and selectivity for PACAP. ALD1910 effectively antagonizes PACAP signaling, is pharmacologically active in vivo, and represents an attractive therapeutic agent for the preventive treatment of migraine.

\section{Acknowledgments}

We gratefully thank Patrick Moss for bioinformatical support and Pei Qi, Joshua Boldman, Malay Chan, Joshua Poole, Mark Burnett, and Carrie Elliott for analytical support.

\section{Authorship Contributions}

Participated in research design: Moldovan Loomis, Dutzar, Ojala, Scalley-Kim, Latham, Allison, Cady, Garcia-Martinez.

Conducted experiments: Moldovan Loomis, Dutzar, Ojala, ScalleyKim, Hendrix, Fan, Mulligan, Kwon, Marzolf, Karasek, Stewart, Billgren, Rubin, Boshaw, Jurchen, Perrino McCulloch.

Performed data analysis: Moldovan Loomis, Dutzar, Ojala, Karasek, Scalley-Kim, Allison, Pederson, Baker, Garcia-Martinez.

Wrote or contributed to the writing of the manuscript: Moldovan Loomis, Latham, Garcia-Martinez.

\section{References}

Akerman S and Goadsby PJ (2015) Neuronal PAC1 receptors mediate delayed activation and sensitization of trigeminocervical neurons: relevance to migraine. Sci Transl Med 7:308ra157.

Akerman S, Holland PR, Summ O, Lasalandra MP, and Goadsby PJ (2012) A translational in vivo model of trigeminal autonomic cephalalgias: therapeutic characterization. Brain 135:3664-3675.

Amin FM, Asghar MS, Guo S, Hougaard A, Hansen AE, Schytz HW, van der Geest RJ, de Koning PJ, Larsson HB, Olesen J, et al. (2012) Headache and prolonged dilatation of the middle meningeal artery by PACAP38 in healthy volunteers. Cephalalgia 32:140-149.

Amin FM, Hougaard A, Schytz HW, Asghar MS, Lundholm E, Parvaiz AI, de Koning PJH, Andersen MR, Larsson HBW, Fahrenkrug J, et al. (2014) Investigation of the pathophysiological mechanisms of migraine attacks induced by pituitary adenylate cyclase-activating polypeptide-38. Brain 137:779-794.

Arimura A, Somogyvári-Vigh A, Miyata A, Mizuno K, Coy DH, and Kitada C (1991) Tissue distribution of PACAP as determined by RIA: highly abundant in the rat brain and testes. Endocrinology 129:2787-2789.

Ashina M, Hansen JM, Á Dunga BO, and Olesen J (2017) Human models of migraine short-term pain for long-term gain. Nat Rev Neurol 13:713-724.

Barbanti P, Aurilia C, Dall'Armi V, Egeo G, Fofi L, and Bonassi S (2016) The phenotype of migraine with unilateral cranial autonomic symptoms documents increased peripheral and central trigeminal sensitization. A case series of 757 patients. Cephalalgia 36:1334-1340.

Barbanti P, Fabbrini G, Pesare M, Vanacore N, and Cerbo R (2002) Unilateral cranial autonomic symptoms in migraine. Cephalalgia 22:256-259.

Baun M, Pedersen MHF, Olesen J, and Jansen-Olesen I (2012) Dural mast cell degranulation is a putative mechanism for headache induced by PACAP-38. Cephalalgia 32:337-345.

Benemei S, Appendino G, and Geppetti P (2010) Pleasant natural scent with unpleasant effects: cluster headache-like attacks triggered by Umbellularia californica. Cephalalgia 30:744-746.

Bhatt DK, Gupta S, Olesen J, and Jansen-Olesen I (2014) PACAP-38 infusion cause sustained vasodilation of the middle meningeal artery in the rat: possible involvement of mast cells. Cephalalgia 34:877-886.

Boni LJ, Ploug KB, Olesen J, Jansen-Olesen I, and Gupta S (2009) The in vivo effect of VIP, PACAP-38 and PACAP-27 and mRNA expression of their receptors in rat middle meningeal artery. Cephalalgia 29:837-847.

Bravman T, Bronner V, Lavie K, Notcovich A, Papalia GA, and Myszka DG (2006) Exploring "one-shot" kinetics and small molecule analysis using the ProteOn XPR36 array biosensor. Anal Biochem 358:281-288.

Burgess T, Coxon A, Meyer S, Sun J, Rex K, Tsuruda T, Chen Q, Ho S-Y, Li L, Kaufman S, et al. (2006) Fully human monoclonal antibodies to hepatocyte growth factor with therapeutic potential against hepatocyte growth factor/c-Metdependent human tumors. Cancer Res 66:1721-1729.

Cheng Y and Prusoff WH (1973) Relationship between the inhibition constant $\left(\mathrm{K}_{1}\right)$ and the concentration of inhibitor which causes 50 per cent inhibition $\left(I_{50}\right)$ of an enzymatic reaction. Biochem Pharmacol 22:3099-3108.

Colbert RA, Balbi D, Johnson A, Bailey JA, and Allen JM (1994) Vasoactive intestinal peptide stimulates neuropeptide $\mathrm{Y}$ gene expression and causes neurite extension in PC12 cells through independent mechanisms. $J$ Neurosci 14:7141-7147.

Csati A, Tajti J, Kuris A, Tuka B, Edvinsson L, and Warfvinge K (2012a) Distribution of vasoactive intestinal peptide, pituitary adenylate cyclase-activating peptide, nitric oxide synthase, and their receptors in human and rat sphenopalatine ganglion. Neuroscience 202:158-168.

Csati A, Tajti J, Tuka B, Edvinsson L, and Warfvinge K (2012b) Calcitonin gene-related peptide and its receptor components in the human sphenopalatine ganglion -- interaction with the sensory system. Brain Res 1435:29-39.

Dinca A, Chien W-M, and Chin MT (2016) Intracellular delivery of proteins with cellpenetrating peptides for therapeutic uses in human disease. Int J Mol Sci 17:263.

Doan N-D, Chatenet D, Létourneau M, Vaudry H, Vaudry D, and Fournier A (2012a) Receptor-independent cellular uptake of pituitary adenylate cyclase-activating polypeptide. Biochim Biophys Acta 1823:940-949.

Doan N-D, Létourneau M, Vaudry D, Doucet N, Folch B, Vaudry H, Fournier A, and Chatenet D (2012b) Design and characterization of novel cell-penetrating peptides from pituitary adenylate cyclase-activating polypeptide. J Control Release 163:256-265. Dostalek M, Gardner I, Gurbaxani BM, Rose RH, and Chetty M (2013) Pharmacokinetics, pharmacodynamics and physiologically-based pharmacokinetic modelling of monoclonal antibodies. Clin Pharmacokinet 52:83-124.

Duchardt F, Fotin-Mleczek M, Schwarz H, Fischer R, and Brock R (2007) A comprehensive model for the cellular uptake of cationic cell-penetrating peptides. Traffic 8:848-866.

Durham PL (2016) Diverse physiological roles of calcitonin gene-related peptide in migraine pathology: modulation of neuronal-glial-immune cells to promote peripheral and central sensitization. Curr Pain Headache Rep 20:48. 
Edelmayer RM, Le LN, Yan J, Wei X, Nassini R, Materazzi S, Preti D, Appendino G, Geppetti P, Dodick DW, et al. (2012) Activation of TRPA1 on dural afferents: a potential mechanism of headache pain. Pain 153:1949-1958.

Edvinsson L (2018) The CGRP pathway in migraine as a viable target for therapies. Headache 58 (Suppl 1):33-47.

Edvinsson L, Haanes KA, Warfvinge K, and Krause DN (2018) CGRP as the target of new migraine therapies - successful translation from bench to clinic. Nat Rev Neurol 14:338-350.

Eftekhari S, Salvatore CA, Johansson S, Chen T-B, Zeng Z, and Edvinsson L (2015) Localization of CGRP, CGRP receptor, PACAP and glutamate in trigeminal ganglion. Relation to the blood-brain barrier. Brain Res 1600:93-109.

Fahrenkrug J, Hannibal J, Tams J, and Georg B (2000) Immunohistochemical localization of the VIP1 receptor (VPAC1R) in rat cerebral blood vessels: relation to PACAP and VIP containing nerves. J Cereb Blood Flow Metab 20:1205-1214.

Frederiksen SD, Warfvinge K, Ohlsson L, and Edvinsson L (2018) Expression of pituitary adenylate cyclase-activating peptide, calcitonin gene-related peptide and headache targets in the trigeminal ganglia of rats and humans. Neuroscience 393: 319-332.

Goadsby PJ (1991) Characteristics of facial nerve-elicited cerebral vasodilatation determined using laser Doppler flowmetry. Am J Physiol 260:R255-R262.

Goadsby PJ, Holland PR, Martins-Oliveira M, Hoffmann J, Schankin C, and Akerman S (2017) Pathophysiology of migraine: a disorder of sensory processing. Physiol Rev 97:553-622.

Gottselig R and Messlinger K (2004) Noxious chemical stimulation of rat facial mucosa increases intracranial blood flow through a trigemino-parasympathetic reflex--an experimental model for vascular dysfunctions in cluster headache. Cephalalgia 24:206-214.

Greenall SA, Adams TE, and Johns TG (2016) Incomplete target neutralization by the anti-cancer antibody rilotumumab. MAbs 8:246-252.

Guo S (2017) The role of genetics on migraine induction triggered by CGRP and PACAP38. Dan Med J 64.

Guo S, Vollesen ALH, Olesen J, and Ashina M (2016) Premonitory and nonheadache symptoms induced by CGRP and PACAP38 in patients with migraine. Pain 157: $2773-2781$.

Hansen JM, Sitarz J, Birk S, Rahmann AM, Oturai PS, Fahrenkrug J, Olesen J, and Ashina M (2006) Vasoactive intestinal polypeptide evokes only a minima headache in healthy volunteers. Cephalalgia 26:992-1003.

Harmar AJ, Fahrenkrug J, Gozes I, Laburthe M, May V, Pisegna JR, Vaudry D, Vaudry H, Waschek JA, and Said SI (2012) Pharmacology and functions of receptors for vasoactive intestinal peptide and pituitary adenylate cyclase-activating polypeptide: IUPHAR review 1. Br J Pharmacol 166:4-17.

Heng BC and Cao T (2005) Making cell-permeable antibodies (transbody) through fusion of protein transduction domains (PTD) with single chain variable fragment $(\mathrm{scFv})$ antibodies: potential advantages over antibodies expressed within the intracellular environment (intrabody). Med Hypotheses 64:1105-1108.

Hoffmann J, Baca SM, and Akerman S (2017) Neurovascular mechanisms of migraine and cluster headache. J Cereb Blood Flow Metab DOI: 10.1177/0271678X17733655 [published ahead of print]

Højland CR, Andersen HH, Poulsen JN, Arendt-Nielsen L, and Gazerani P (2015) A human surrogate model of itch utilizing the TRPA1 agonist trans-cinnamaldehyde. Acta Derm Venereol 95:798-803.

Jansen-Olesen I, Baun M, Amrutkar DV, Ramachandran R, Christophersen DV, and Olesen J (2014) PACAP-38 but not VIP induces release of CGRP from trigeminal nucleus caudalis via a receptor distinct from the PAC1 receptor. Neuropeptides 48:53-64.

Jansen-Olesen I and Hougaard Pedersen S (2018) PACAP and its receptors in cranial arteries and mast cells. J Headache Pain 19:16.

Kaiser EA and Russo AF (2013) CGRP and migraine: could PACAP play a role too? Neuropeptides 47:451-461.

Khan S, Olesen A, and Ashina M (2017) CGRP, a target for preventive therapy in migraine and cluster headache: systematic review of clinical data. Cephalalgia DOI: 10.1177/0333102417741297 [published ahead of print].

Khan S, Schoenen J, and Ashina M (2014) Sphenopalatine ganglion neuromodulation in migraine: what is the rationale? Cephalalgia 34:382-391.

Kumar S, Pioszak A, Zhang C, Swaminathan K, and Xu HE (2011) Crystal structure of the PAC1R extracellular domain unifies a consensus fold for hormone recognition by class B G-protein coupled receptors. PLoS One 6:e19682.

Kunkler PE, Ballard CJ, Oxford GS, and Hurley JH (2011) TRPA1 receptors mediate environmental irritant-induced meningeal vasodilatation. Pain 152:38-44.

Levin M, Silberstein SD, Gilbert R, Lucas S, Munsie L, Garrelts A, Kennedy K, Everman N, and Pearlman E (2018) Basic considerations for the use of monoclonal antibodies in migraine. Headache 58:1689-1696.

Levy D, Burstein R, and Strassman AM (2006) Mast cell involvement in the pathophysiology of migraine headache: a hypothesis. Headache 46 (Suppl 1):S13-S18.

Lightwood DJ, Carrington B, Henry AJ, McKnight AJ, Crook K, Cromie K, and Lawson ADG (2006) Antibody generation through B cell panning on antigen followed by in situ culture and direct RT-PCR on cells harvested en masse from antigen-positive wells. J Immunol Methods 316:133-143.

Loder E (2010) Triptan therapy in migraine. N Engl J Med 363:63-70.

Lukacs M, Tajti J, Fulop F, Toldi J, Edvinsson L, and Vécsei L (2017) Migraine, neurogenic inflammation, drug development - pharmacochemical aspects. Curr Med Chem 24:3649-3665.

Lutz EM, Ronaldson E, Shaw P, Johnson MS, Holland PJ, and Mitchell R (2006) Characterization of novel splice variants of the PAC1 receptor in human neuroblastoma cells: consequences for signaling by VIP and PACAP. Mol Cell Neurosci 31:193-209.

Markovics A, Kormos V, Gaszner B, Lashgarara A, Szoke E, Sandor K, Szabadfi K, Tuka B, Tajti J, Szolcsanyi J, et al. (2012) Pituitary adenylate cyclase-activating polypeptide plays a key role in nitroglycerol-induced trigeminovascular activation in mice. Neurobiol Dis 45:633-644.
Marschall ALJ, Frenzel A, Schirrmann T, Schüngel M, and Dübel S (2011) Targeting antibodies to the cytoplasm. MAbs 3:3-16.

Mason BN and Russo AF (2018) Vascular contributions to migraine: time to revisit? Front Cell Neurosci 12:233.

McNamara CR, Mandel-Brehm J, Bautista DM, Siemens J, Deranian KL, Zhao M, Hayward NJ, Chong JA, Julius D, Moran MM, et al. (2007) TRPA1 mediates formalin-induced pain. Proc Natl Acad Sci USA 104:13525-13530.

Miyata A, Jiang L, Dahl RD, Kitada C, Kubo K, Fujino M, Minamino N, and Arimura A (1990) Isolation of a neuropeptide corresponding to the N-terminal 27 residues of the pituitary adenylate cyclase activating polypeptide with 38 residues (PACAP38). Biochem Biophys Res Commun 170:643-648.

Mizuta K, Kuchiiwa S, Saito T, Mayanagi H, Karita K, and Izumi H (2002) Involvement of trigeminal spinal nucleus in parasympathetic reflex vasodilatation in cat lower lip. Am J Physiol Regul Integr Comp Physiol 282:R492-R500.

Moody TW, Ito T, Osefo N, and Jensen RT (2011) VIP and PACAP: recent insights into their functions/roles in physiology and disease from molecular and genetic studies. Curr Opin Endocrinol Diabetes Obes 18:61-67.

Mulder H, Uddman R, Moller K, Zhang YZ, Ekblad E, Alumets J, and Sundler F (1994) Pituitary adenylate cyclase activating polypeptide expression in sensory neurons. Neuroscience 63:307-312.

Nassini R, Materazzi S, Vriens J, Prenen J, Benemei S, De Siena G, la Marca G Andrè E, Preti D, Avonto C, et al. (2012) The 'headache tree' via umbellulone and TRPA1 activates the trigeminovascular system. Brain 135:376-390.

Neree AT, Nguyen PT, and Bourgault S (2015) Cell-penetrating ability of peptide hormones: key role of glycosaminoglycans clustering. Int J Mol Sci 16:27391-27400. Obermann M and Holle D (2016) Recent advances in the management of migraine. F1000Res 5:2726.

Okragly AJ, Morin SM, DeRosa D, Martin AP, Johnson KW, Johnson MP, and Benschop RJ (2018) Human mast cells release the migraine-inducing factor pituitary adenylate cyclase-activating polypeptide (PACAP). Cephalalgia 38:1564-1574.

Onoue S, Endo K, Yajima T, and Kashimoto K (2002) Pituitary adenylate cyclase activating polypeptide regulates the basal production of nitric oxide in PC12 cells. Life Sci 71:205-214.

Pantaloni C, Brabet P, Bilanges B, Dumuis A, Houssami S, Spengler D, Bockaert J, and Journot L (1996) Alternative splicing in the N-terminal extracellular domain of the pituitary adenylate cyclase-activating polypeptide (PACAP) receptor modulates receptor selectivity and relative potencies of PACAP-27 and PACAP-38 in phospholipase C activation. J Biol Chem 271:22146-22151.

Pisegna JR and Wank SA (1996) Cloning and characterization of the signal transduction of four splice variants of the human pituitary adenylate cyclase activating polypeptide receptor. Evidence for dual coupling to adenylate cyclase and phospholipase C. J Biol Chem 271:17267-17274.

Rahmann A, Wienecke T, Hansen JM, Fahrenkrug J, Olesen J, and Ashina M (2008) Vasoactive intestinal peptide causes marked cephalic vasodilation, but does not induce migraine. Cephalalgia 28:226-236.

Ramsey JD and Flynn NH (2015) Cell-penetrating peptides transport therapeutics into cells. Pharmacol Ther 154:78-86.

Riechmann L, Clark M, Waldmann H, and Winter G (1988) Reshaping human antibodies for therapy. Nature 332:323-327.

Rubio-Beltrán E, Correnti E, Deen M, Kamm K, Kelderman T, Papetti L, Vigneri S, MaassenVanDenBrink A, and Edvinsson L; European Headache Federation Schoo

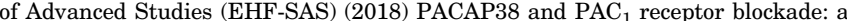
new target for headache? $J$ Headache Pain 19:64.

Russo AF (2015) Calcitonin gene-related peptide (CGRP): a new target for migraine. Annu Rev Pharmacol Toxicol 55:533-552.

Schytz HW, Birk S, Wienecke T, Kruuse C, Olesen J, and Ashina M (2009) PACAP38 induces migraine-like attacks in patients with migraine without aura. Brain 132: $16-25$.

Schytz HW, Holst H, Arendt-Nielsen L, Olesen J, and Ashina M (2010a) Cutaneous nociception and neurogenic inflammation evoked by PACAP38 and VIP. J Headache Pain 11:309-316.

Schytz HW, Olesen J, and Ashina M (2010b) The PACAP receptor: a novel target for migraine treatment. Neurotherapeutics 7:191-196.

Seeliger S, Buddenkotte J, Schmidt-Choudhury A, Rosignoli C, Shpacovitch V, von Arnim U, Metze D, Rukwied R, Schmelz M, Paus R, et al. (2010) Pituitary adenylate cyclase activating polypeptide: an important vascular regulator in human skin in vivo. Am J Pathol 177:2563-2575.

Spengler D, Waeber C, Pantaloni C, Holsboer F, Bockaert J, Seeburg PH, and Journot L (1993) Differential signal transduction by five splice variants of the PACAP receptor. Nature 365:170-175.

Steiner TJ, Stovner LJ, and Birbeck GL (2013) Migraine: the seventh disabler. $J$ Headache Pain 14:1-2.

Steiner TJ, Stovner LJ, Vos T, Jensen R, and Katsarava Z (2018) Migraine is first cause of disability in under $50 \mathrm{~s}$ : will health politicians now take notice? J Headache Pain 19:17.

Sun C, Song D, Davis-Taber RA, Barrett LW, Scott VE, Richardson PL, Pereda-Lopez A, Uchic ME, Solomon LR, Lake MR, et al. (2007) Solution structure and mutational analysis of pituitary adenylate cyclase-activating polypeptide binding to the extracellular domain of PAC1-RS. Proc Natl Acad Sci USA 104:7875-7880.

Syed AU, Koide M, Braas KM, May V, and Wellman GC (2012) Pituitary adenylate cyclase-activating polypeptide (PACAP) potently dilates middle meningeal arteries: implications for migraine. J Mol Neurosci 48:574-583.

Tajti J, Tuka B, Botz B, Helyes Z, and Vécsei L (2015) Role of pituitary adenylate cyclase-activating polypeptide in nociception and migraine. CNS Neurol Disord Drug Targets 14:540-553.

Tajti J, Uddman R, and Edvinsson L (2001) Neuropeptide localization in the "migraine generator" region of the human brainstem. Cephalalgia 21:96-101.

Tajti J, Uddman R, Möller S, Sundler F, and Edvinsson L (1999) Messenger molecules and receptor mRNA in the human trigeminal ganglion. J Auton Nerv Syst 76: 176-183. 
Tchoumi Neree A, Nguyen PT, Chatenet D, Fournier A, and Bourgault S (2014) Secondary conformational conversion is involved in glycosaminoglycans-mediated cellular uptake of the cationic cell-penetrating peptide PACAP. FEBS Lett 588:4590-4596.

Theoharides TC, Donelan J, Kandere-Grzybowska K, and Konstantinidou A (2005) The role of mast cells in migraine pathophysiology. Brain Res Brain Res Rev 49:65-76.

Tuka B, Helyes Z, Markovics A, Bagoly T, Németh J, Márk L, Brubel R, Reglődi D, Párdutz A, Szolcsányi J, et al. (2012) Peripheral and central alterations of pituitary adenylate cyclase activating polypeptide-like immunoreactivity in the rat in response to activation of the trigeminovascular system. Peptides 33:307-316.

Tuka B, Helyes Z, Markovics A, Bagoly T, Szolcsányi J, Szabó N, Tóth E, Kincses ZT, Vécsei L, and Tajti J (2013) Alterations in PACAP-38-like immunoreactivity in the plasma during ictal and interictal periods of migraine patients. Cephalalgia 33:1085-1095.

Uddman R, Goadsby PJ, Jansen I, and Edvinsson L (1993) PACAP, a VIP-like peptide: immunohistochemical localization and effect upon cat pial arteries and cerebral blood flow. J Cereb Blood Flow Metab 13:291-297.

Uddman R, Tajti J, Hou M, Sundler F, and Edvinsson L (2002) Neuropeptide ex pression in the human trigeminal nucleus caudalis and in the cervical spinal cord $\mathrm{C} 1$ and C2. Cephalalgia 22:112-116.
Uddman R, Tajti J, Möller S, Sundler F, and Edvinsson L (1999) Neuronal messengers and peptide receptors in the human sphenopalatine and otic ganglia. Brain Res 826:193-199.

Vaudry D, Falluel-Morel A, Bourgault S, Basille M, Burel D, Wurtz O, Fournier A, Chow BKC, Hashimoto H, Galas L, et al. (2009) Pituitary adenylate cyclaseactivating polypeptide and its receptors: 20 years after the discovery. Pharmacol Rev 61:283-357.

Vollesen ALH and Ashina M (2017) PACAP38: emerging drug target in migraine and cluster headache. Headache 57 (Suppl 2):56-63.

Walker CS, Sundrum T, and Hay DL (2014) PACAP receptor pharmacology and agonist bias: analysis in primary neurons and glia from the trigeminal ganglia and transfected cells. Br J Pharmacol 171:1521-1533.

Zagami AS, Edvinsson L, and Goadsby PJ (2014) Pituitary adenylate cyclase activating polypeptide and migraine. Ann Clin Transl Neurol 1:1036-1040.

Address correspondence to: Leon F. Garcia-Martinez, Alder BioPharmaceuticals, Inc., 11804 North Creek Parkway South, Bothell, WA 98011. E-mail: lgarcia-martinez@alderbio.com 